\title{
The Reform of Justice in Albania
}

\author{
Alesia Balliu \\ European University of Tirana, Tirana, Albania \\ Email: balliualesia20@gmail.com
}

How to cite this paper: Balliu, A. (2020). The Reform of Justice in Albania. Beijing Law Review, 11, 709-728.

https://doi.org/10.4236/blr.2020.113043

Received: July 8, 2020

Accepted: September 7, 2020

Published: September 10, 2020

Copyright (c) 2020 by author(s) and Scientific Research Publishing Inc. This work is licensed under the Creative Commons Attribution International License (CC BY 4.0).

http://creativecommons.org/licenses/by/4.0/

\begin{abstract}
The justice reform in Albania has been one of the country's major steps to tackle corruption in all levels, to strengthen the integrity of the public administration, to support the independence and/or functional autonomy of law enforcing and independent institutions, to promote a more effective and efficient institutional cooperation and coordination, to promote public trust in juridical system and to accelerate the process of integration in the European Union. This study, through a qualitative methodology, aims at analyzing the main steps conducted by Albanian governments in initiating and adapting the justice reform, the role of EU in this process, the current progress achieved till the EU accession negotiations as well as further recommendations in the road towards EU membership. In the case of Albania, the acceleration of reforms in the judicial system among other reforms was a strong reason that the European Commission opened the accession negotiations with Albania in 25 March 2020. Based on this fact, the study enriches the juridical research in Albania and beyond.
\end{abstract}

\section{Keywords}

Reform, Justice, Albania, EU Acquis, Vetting Process

\section{Introduction}

Justice, together with other fundamental rights, such as health, security and freedom, represents one of the most important human rights. For this reason, almost every country, including Albania has built a network of courts, more or less comprehensive, with the aim of bringing justice to the citizens as much as possible.

During the years, the European Commission has drawn attention to the fact that the judicial system in Albania had remained highly affected by politicization, corruption and poor inter-institutional cooperation (European Commission, 2016). Although the independence and impartiality of the judicial system 
was sanctioned and materialized in Albanian legislation, in practice it was endangered by highly politicized ways by each appointing judges of the High Court and the Constitutional Court, as well as the wide discretion enjoyed by the High Council Justice and Attorney General in career management of judges and prosecutors. In this context, with the aim of addressing the identified problems, the necessary constitutional and legislative interventions have been carried out through judicial reform, and the good governance of the judiciary management bodies is aiming at the independence, accountability, efficiency and transparency of the judiciary.

At the core of the Justice Reform was the adoption by the Assembly of constitutional amendments on 21 July 2016, where out of 26 articles of the Albanian Constitution pertaining to the justice system, the Reform amended 21 of them and at least 23 new points are added in the Constitution. The complex reform package, composed of six laws, structurally modifies the Albanian Constitution, modifying as many as 45 articles (Murati, 2019). Furthermore, the three institutions set out in the Constitution were merged and the creation of at least 12 new institutions was envisaged, such as a new special prosecution office against corruption and organized crime, known under the acronym SPAK, a new specialized court against corruption, reorganized judicial and prosecutorial councils, National Bureau of Investigation, judicial appointments councils and a new office of the High Inspector of Justice.

The adoption of the constitutional amendments was followed by the adoption of the package of Organic Laws, which highlights the law on the temporary re-evaluation of judges and prosecutors of the Republic of Albania. This is called also the process of vetting which is evaluated as the centre of the juridical reform (Likmeta, 2019).

In 2019, the progress report of European Commission noted that the implementation of justice reform has continued consistently and resulted in good progress overall (European Commission, 2019). Also, the vetting process, as one of the most important mechanisms applied to the transitional democracies in order to evaluate the suitability of judges and prosecutors, part of justice reform has produced tangible results. In this context, until June 2020, institutions such as Independent Qualification Commission, the Public Commissioners and the Appeal Chamber are functional and working under the oversight of the International Monitoring Operation (IMO), deployed by the European Commission in cooperation with the United States of America (European Commission, 2020). Regarding the independent judicial structures, such as High Judicial Council, High Prosecutorial Council, Justice Appointment Council and High Justice Inspector, European Commission noted that they have been operating effectively throughout 2019 (European Commission, 2020). Also, progress is being made regarding the reconstitution of the Constitutional Court in appointing new members as a result of the vetting process. The establishment of the Special Anti-Corruption and Organized Crime Structure (SPAK) was finalised in 2019 and the Special Prosecution Office (SPO) within this structure is fully operative. Moreover, Na- 
tional Bureau of Investigation is functional including even two criminal justice experts from the EU (European Commission, 2020). Moreover, according to the Commission Staff Working Document for Albania, the work of these institutions has resulted to $60 \%$ of the vetted magistrates' dismissal or resigned (European Commission, 2020).

However, there are also critics regarding the implementation process of the juridical reform. These critics are related with the need for a faster pace, for better quality in the formatting of institutions. Based on the study report of the experts of the Albanian Helsinki Committee, in the period 2017-2018, the establishment and functioning of vetting institutions was accompanied by delays, which has affected the functioning of institutions such as the High Judicial Council, the High Prosecution Council, Judicial Appointments Council, High Inspector of Justice (Skëndaj, Caka, \& Bogdani, 2018). Despite the fact that the removal of a large number of judges and prosecutors from office is evidence of the effectiveness of the vetting process, this has led to a stalemate in the justice system and delays in access to justice and the efficiency of trial for citizens. In this regard, Albanian government is conducting a more holistic and structural approach to ensure the sustainability and effectively of the vetting as an institutional measure. Despite the obstacles, the acceleration of reforms in the judicial system among other reforms was the reason that the European Commission opened the accession negotiations with Albania in 25 March 2020.

In this context, is important to analyze in details, through a qualitative methodology of literature review, the main steps conducted by Albanian governments in initiating and adapting the justice reform, the role of $\mathrm{EU}$ in this process, the current progress achieved till the accession negotiations as well as further recommendations in the road towards EU membership. This academic study enriches the juridical research in Albania, because of the importance of the juridical reform and especially the process of vetting in administrating the right, strengthening of the rule of law and trust of citizens in the judiciary system. Moreover, it presents the importance of the reform justice for Albania in getting the EU acquis, or the rights and obligations that are binding on all EU Members.

More than four and a half years have passed since the approval of the justice reform, on 21 July 2016 in Albania, under strong pressure both from the USA and the EU. Many opinions has derived for after the starting of implementation the reform of Justice in Albania form national and international sphere, aiming to point an analyse the progress of reform since the beginning of it. According to the Director for Western Balkans at the European Commission and Chair of the International Monitoring Operation, G. R. Calavera, Albania must be determined to continue the full implementation of justice reform for the benefit of its citizens (IBNA, 2020). Moreover, clear and concrete achievements in the implementation of justice reform represent critical factors for advancing the European aspirations of Albania and its citizens (IBNA, 2020).

Deriving from the international point of views on Albanian justice reform progress, we see that the Albanian state also has a positive attitude on how the 
justice reform has gone till far, and how it will continue in the future. According to Albanians Minister of Justice, Mrs. Etilda Gjonaj, until yesterday the judges and prosecutors had returned to a corporation in which it was impossible to seize (Ministry of Justice, 2020a). While today she stated, we see judges and prosecutors who do not feel themselves passing the process have actually resign, as well as judges and prosecutors who cannot pass the Vetting process, and that is exactly why Albanian citizens feel confidence in the Reform of Justice. Gjonaj also emphasized that the Government has undertaken all needed legislative and law-making initiatives, and their dedication in this process can be seen also in their financial support within the implementation of the Justice Reform.

The Ministry of Justice together with international partners will guarantee an independent, efficient and fair justice system (Marini, 2018). The government is in fact publicly committed to improving the quality of services Albanian citizens receive from the Ministry of Justice and its dependence organs. According to Mrs. Gjonaj, financial support for justice reform from Albania, in the 2020 budget has increased by $11 \%$ or 6 million ALL compared to last year, a budget that helps new justice institutions (Fortuzi, 2019). According to Mrs. Gjonaj, justice reform is the most important reform that Albania has undertaken in the last 30 years (Ministry of Justice, 2020a). In this regard, government expectations relate to an objective, impartial evaluation process and at a much better pace, eliminating some procrastination issues that may create misperceptions about the process, better prioritizing vetting entities and its protection from any kind of illegal influence on the decision-making process. Also, the expectations are oriented towards the new institutions of government of the justice system which must prove responsibility, proactive role and much better transparency in their decision-making (Ministry of Justice, 2020b). The unconditional recommendations given by the European Commission to open the negotiations with Albania in 25 March 2020, was attributed precisely to the positive results Albania had with the Justice Reform, and not only with its design, but also on the concrete results that are given and are visible in relation to the Vetting process.

\section{Albania's Main Constitutional Changes}

As we stated above, Albania is undergoing a profound justice reform (Bogdani, 2017). In this context, Albanian parliament has undertaken the initiative to reform the whole justice sector. To achieve this aim, a special assembly appointed a special committee to work on three important topics, which has compiled a comprehensive report on the existent situation of the justice system; prepared a strategic document with the objectives of the reform; and has drafted the legislation changes necessary to achieve all the proposed objectives. This committee was established with a group of high-level experts, technical secretariat, and several external advisors, with the main focus: the process of reforming the justice system in Albania. These groups of experts have now been working for more than two years in the seven pillars of the reform. The main purpose was to limit 
the overwhelming power of magistrates, increasingly "suspected" of corruption, ties with the world of crime and above all of a "personal" administration of public affairs, stem the enormous influence of political power over the judiciary, to restore the trust of citizens in institutions through the creation of a culture oriented towards values of probity, a sense of duty, respect for functions, institutions and justice and of course, to increase the level of professionalism of judges. In this regard, the necessary constitutional and legislative interventions have been carried out through judicial reform, and the good governance of the judiciary management bodies is aiming at the independence, accountability, efficiency and transparency of the judiciary.

In this context, Albanian Parliament adopted Constitutional Amendments in 2016, to launch a deep and comprehensive justice system reform to tackle corruption in all levels (European Commission, 2016). The changes affect some important legal moments, reconceiving and detailing the application of some constitutional principles such as the independence and impartiality of the judiciary. These changes aim at amending the functions of some of the constitutional Albanian institutions. The changes affect some parts of the Constitution, where changes in the court system and the prosecution stand out. One of the main pillars of the functioning of democracy and the rule of law is judicial power, which guarantees the protection of the fundamental freedoms and fundamental rights. The lack of independence and impartiality during the functioning of the judicial system, widespread corruption of judges and judicial administration, and the lack of accountability, transparency, professionalism, efficiency and the lack of public trust in the system were the main reasons behind the approval of the new constitutional reform on justice system in Albania. Through the changes in the ninth part of the Constitution, which refers precisely to the courts, the lawmaker aims to address the existing problems through increased access and effectiveness in the judicial system through the reorganization of courts in accordance with European standards.

The proclamation of the Constitution prescribes that, the Albanian people with faith in universal values, are determined to build a state of law, social and democratic, and also to guarantee the fundamental human rights and freedoms, along with its recent amendments in 2016 with specifically aiming the reform of justice and the fight against corruption. That is why, in line with EU requirements for combating corruption and organized crime and based on the constitutional proclamation, Albanian Parliament on July 2016 approved those constitutional amendments, and amongst other provisions addressing justice reform issues, also the Special Prosecution Office/SPO; this article, prescribes another unit the Special Investigation Unit/SIU that will be subordinate to SPO, both these two institutions will enjoy a special status since they are designed to be independent from the General Prosecution.

The Special Prosecution Office was established, as prescribed by Article 148/4 of the Constitution. Following the approval of Constitution amendments, Par- 
liament approved also Law 95/2016 "On the Organization and Functioning of Institutions for Combating Corruption and Organized Crime", a special law that elaborates in detail the status, competences, jurisdiction, composition and relationships of these two institutions SPO and SIU with other institutions and police officers. SIU Law 95/2016 has been renamed as National Bureau of Investigation/NBI. In addition, two institutions shall be called Special Anti-Corruption and Organized Crime Structure/SPAK and that will include the Special Prosecution Office and the independent investigation unit. This institution will prosecute and investigate criminal offenses of corruption, organized crimes and criminal charges against high state officials. Albanian Assembly approved also a special law, which aims to establish SPAK (Special Prosecution against Corruption) to exercise the competencies effectively and independently from any outside or inside inappropriate influence. In addition, the law also provides establishment of the Independent Investigations Unit which will investigate and prosecute crimes of corruption and organized crime, as well as crimes committed by high state officials, independent from any outside or inside inappropriate influence.

Cooperation and coordination between central and local governments have been, over the years, problematic in Albania and guided by political affiliation and influence. But this coordination is necessary in order for the reform of justice to be fully implemented. This is one of the recommendations of the Congress of Local and Regional Authorities of the Council of Europe for Albania. Improving this relationship is necessary to achieve constructive dialogue and institutional cooperation between the central agencies and local units. Intergovernmental relations will be improved through the establishment of institutional mechanisms of dialogue as well as adoption of relevant legislation. Communication between the central and local governments takes place in two forms: through direct consultation by sector ministries with different Local Units during the policy and strategic planning processes; and through the local government associations.

While there are no clear regulations formalizing the consultation process between local government associations and the central government, the central administration accepts that consultation with local government representatives is either very limited or lacking in the drafting of many important legislation or policy reform documents. Legal changes must take place in order to formalize by law, the process by which central authorities consult local authorities. This is also quite important in order to ensure consultation takes place in due time and in an appropriate way on matters that directly concern local government activity.

\section{The Major Legislative Changes as Part of the Justice Reform}

Reform in the justice system in Albania is conceived of over 7 base pillars. Specifically, these pillars are: The justice system under the Constitution and the Con- 
stitutional Court; Judicial power; Criminal Justice; Legal Education; Legal services and free professions; Measures in the fight against corruption; Funding and infrastructure support of the system.

These 7 pillars are also the main components of the Justice System Analysis in Albania. The new Legal Acts on Justice System Bodies, based on the 7 pillars, lay down rules on how to organize and operate four new constitutional bodies guaranteeing a fair, independent, transparent and credible justice system governance. The executing bodies of the justice reform are the High Judicial Council (HRC), the High Council of Prosecutors (PJC), the High Inspector of Justice (ILD) and the Council of Appointments (EC). In addition, these legal acts, in chapters and separate sections, provide for assignments and responsibilities for other institutions such as the Chambers of Advocacy, the Notaries 'Chambers, the Pedagogues' Corps and the Rectorate, the School of Magistrates.

The constitutional changes of Albania consist on more than 23 Laws which has changed. Here we will analyse some of the most important laws, but also the most discussed laws of the reform of justice in Albania. These laws are especially important at the moment because Albania is currently without an operating Constitutional court and with some other courts which are short in members, so have difficulty operating. The constitutional amendments were voted unanimously by 140 MPs on July 22, 2016 (European Union, 2017). The first change is reflected in Article 43, where the right to appeal against a court decision is sanctioned. The new constitution, in cases against minor criminal offenses, civil or administrative matters of minor importance or value, provides for the possibility of limiting the right to appeal by law.

Beginning with the Constitutional Court (CC), the lawmaker has made some changes that focus on ensuring the independence and effectiveness of the CC by defining the rules and criteria for the selection of candidacies for constitutional judges. The new formula envisions the election of $1 / 3$ of the members by the President of the Republic, $1 / 3$ of the Assembly by a qualified majority of $3 / 5$ of the votes and $1 / 3$ by the Supreme Court troops, avoiding the blocking of the process of appointing constitutional judges found in recent years. Each of the above bodies should select between the three candidates nominated by the Council of Appointments in Justice for each vacancy. Also it is aiming in ensuring the collective functioning of the NLC and avoiding extended posture. Another purpose is respecting the duration and inviolability of the constitutional mandate (9 years) and also establishing clear modalities and deadlines for issues related to the dismissal and termination of the mandate of judges. Inclusion of constitutional judges in the accountability and accountability system through clear material and procedural discipline of their disciplinary responsibility, providing that their system of disciplinary responsibility is under the authority of the MCR itself (Council of Europe, 2016a: Articles 125-128) is another important aim, together with the creation of mechanisms for a more accurate identification of issues aiming to avoid it as a fourth degree judgment in function of the 
economy and judicial efficiency (Council of Europe, 2016b: Articles 131).

Major changes has been done also envisions in the administration of the court system in Albania by attempting to reform it. The new constitution aims to create a new spirit of court functioning and administration, a spirit that aims to be reflected in the laws and other acts that will follow. Through these changes, the legislator intends to put an end to corruption, beyond the length of the trials and the lack of professionalism for judges, as well as to restore the people's trust in the justice system. Courts are seen as the main contributor to strengthening the rule of law and the fight against corruption and organized crime, while poor judicial performance is a factor that obstructs legal certainty and economic development of the country. On the other hand, it should be emphasized that public confidence in the efficiency, honesty and professionalism of the court has been very low. The goals of judicial reform should be based on sound principles that improve the quality of justice for citizens and should include the following aspects: improve the image of the judiciary; ensure an efficient system that does not compromise the quality of justice and access to justice; increase public confidence in the judicial system; improve the quality of access to justice, especially for vulnerable categories.

The new constitution reverses or re-establishes some of the old justice institutions (e.g. the High Council of Justice and the National Judicial Conference) and sanctions new institutions such as the High Judicial Council, the High Prosecutor's Office and the High Inspectorate of Justice (Council of Europe, 2016b: Articles 147/a).

On the Organization and Functioning of Institutions to Fight Corruption and Organized Crime, a law was drafted to implement the following constitutional changes: Article 135, which establishes the creation of a special court that judges the criminal offenses of corruption and organized crime, as well as criminal charges against senior officials (in office or in the past); Article 148, which establishes the creation of the Special Prosecution Office and the Special Investigative Unit for criminal prosecution and investigation of criminal offenses of corruption, organized crime and criminal cases against (former) senior officials; and Article 148/d, which sets out the criteria and functions of the Special Prosecution Office and the National Bureau of Investigation.

Law No. 98/2016, regulates the organization and functioning of the court system in the Republic of Albania. It provides clear rules regarding the jurisdiction and functioning of all courts in the judicial system. More specifically, it regulates the manner of determining the territorial jurisdiction of courts, the assignment of sections to courts, the definition of the composition of judicial bodies, the map of courts under the jurisdiction of the High Judicial Council; internal organization in the courts; functioning of the judicial administration, as well as the status of employees in the court.

Unlike the previous system of regulating the above issues, this law provides for a consolidated system under the competence of the High Judicial Council to 
regulate, enforce and supervise in practice the organization and functioning of court work.

Law No. 99/2016 defines the rules of organization and functioning of the Constitutional Court, the status of a judge, the submission of claims and their consideration, the constitutional principles and rules of constitutional judgment, the taking of decisions and their execution. Law No. 99/2016 aims to make the Constitutional Court (CC) more effective in decision-making and strengthens the role and independence of the CC, emphasizing the full organizational, administrative and financial independence for the accomplishment of certain tasks in the Constitution as well as its function as the body that solves the constitutional nature of the disputes and makes the final interpretation of the Constitution.

Law No. 115/2016 defines rules for the organization and functioning of the High Judicial Council (HRC), the High Council of Prosecutors (PJC), the High Inspectorate of Justice (ILD) and the Council of Appointments in Justice (KED), four constitutional bodies, the guarantors of a fair, independent, transparent and credible governance of the justice system. The purpose of this law is good governance of the justice system in the function of independence, accountability, efficiency and transparency. These bodies partially replace the existing organs.

As a result of the failure to establish new organs of the justice system as well as parliamentary procedures, the Supreme Court and the Constitutional Court were faced with the lack of judges. In this moment, the Constitutional Court currently consists of 7 judges (out of 9), as two judges of this court have finished their mandate and have left the office. Only one judge remains in office. Even for the Supreme Court, which consists of 19 members, the absence of a judicial body has resulted in difficulties in its functioning. The court currently operates with a 9 members, one of whose term has been terminated.

\section{The Re-Evaluation of Judges and Prosecutors in Albania as Part of the Justice Reform}

As an integral part of the constitutional changes, the package aimed at reforming the justice system and restoring the trust of citizens to the rule of law, the Albanian Parliament adopted Law No. 84/2016 "On the Provisional Reassessment of Judges and Prosecutors in the Republic of Albania" or as widely known in the public "The vetting process". Vetting, is the process that serves to exclude public officials who do not have integrity in fulfilling the duty and thus restore public confidence in the work of state institutions (Lexferanda, $\mathrm{n} / \mathrm{a}$ ). The vetting process as a rule is performed by checking someone's figure before being offered a job. Depending on the job or project, the vetting process can be based on the control of skills, personality, property or any other factor related to the purpose of vetting. In Albania, the vetting process has been regarded as essential in implementing justice reform because an independent and impartial justice system affects the rule of law in the country. 
The purpose of this law is to establish special rules for the re-evaluation of all judges and prosecutors as a process that will serve to evaluate their professional preparation, moral integrity and property verification, as well as to discover possible links or influences from organized crime and corruption. More specifically, vetting is the transitional reassessment of all judges and prosecutors of Albania, to guarantee the functioning of the rule of law, the independence of the justice system, and the restoration of public confidence in the institutions of this system. Institutions envisaged to carry out the reevaluation process are Independent Qualification Commission (who makes the initial decision), the Special Appellate Panel (which makes the final decision in case of animation) and the Public Commissioners (who represent the public interest before the Special Panel). With the entry into force of the vetting process, prosecutors and senior judicial system officials were all subjected to a detailed examination of the credentials, c.d "The Vetting" process. According to the law of vetting, are subjects of re-evaluation that are subject to the vetting process, the following persons: All judges, including the judges of the Constitutional Court and the High Court; All prosecutors including the General Attorney; Chief Inspector as well as all other inspectors at the High Council of Justice; All legal advisers at the Constitutional Court and the High Court, legal assistants at the administrative courts and legal assistants at the General Prosecutor's Office; Former judges, former prosecutors, former legal advisors of the Constitutional Court and Supreme Court, who have worked in these positions for at least three years, if they submit a request to undergo a revaluation process.

This process and general control of work, of the professionalism, of the assets and of any links with the crime, are carried out by two other new institutions established by law n. 84/2016 (Lexferanda, n/a) of the reform package, the Independent Qualifications Commission and the Appeals Board, which means that this process will not be transferred to the existing judicial system, as judges are subject to evaluation. These institutions will also be monitored by an International Monitoring Operation, composed of judges and prosecutors selected from various EU member states (Merruko, 2017).

The commission is organized into 4 trial panels composed of 3 members, who are assigned by lot, while the Appellate Panel judges in judges composed of 5 judges (Shteti Web, 2016). Both are assisted by the International Monitoring Operation, a commission managed by the EU, with experts from the judicial system of member countries, with an experience of at least 15 years. The first real effects of the reform can be touched by investigating the work done by the two institutions mentioned above, consequently the research is limited to these two organs. The decision of the Independent Committee, which may be appealed to the Appeals Board, is based on the collection of evidence relating to three pillars; a) the patrimonial evaluation and uses it lawfully origin; b) control of the figure (personal and family); and finally c) the assessment of professional skills.

The patrimonial evaluation is the first component of the vetting law and the 
one that has encountered the greatest resistance from judges and prosecutors, causing, as a result, a high number of resignations not to undergo verification procedures. All judges and prosecutors are able to declare their assets by allowing institutions to conduct an active investigation into his/her assets. Anyone under assessment must be able to justify his/her assets based on legal sources (i.e. income and tax returns) (Shteti Web, 2016).

The control of the figure consists of verifying the assessments, statements and other data that aim to identify the connections with individuals involved in organized crime. If the person under assessment, after verification, is found guilty after having clear links to figures of organized crime, he/she will be dismissed if he/she is unable to prove otherwise (Shteti Web, 2016).

The assessment of professional skills ensures that each subject will be subject to assessment criteria for specific skills, by profession. In the case of judges, they will be judged on their ability to judge, while in the case of prosecutors; they will be assessed on the basis of their ability to conduct investigations. Also, organizational skills, ethics and personal qualities will be assessed, based on the standards provided by law. Individuals assessed as "absent" are recommended to pursue a training program at the School of Magistrates, while assessments as inappropriate for a particular skill lead to their dismissal (Shteti Web, 2016). The role of the Albanian National Security Authority is responsible for conducting background assessments of judges and prosecutors (Council of Europe, 2016a).

The priority of control was given to the jurists belonging to the highest ranks of the judiciary. The reason for this "pyramid scheme" was to identify suitable magistrates for the creation of new judicial bodies. Today, according to data from the Independent Qualification Commission and the Special Appellate Panel, judges of the Constitutional Court, the Supreme Court and the General Prosecutor's Office have been initially evaluated (Exit News, 2020).

The situation is somewhat critical and unprecedented because it seriously risks violating the rights of citizens and undermining the balance of the three powers. Until June 2020 (Exit News, 2020) 101 magistrates have been fired, 90 have been confirmed in office and 39 have resigned. Mostly magistrates have been fired due to non-justification of their property. The Special Appellate Panel has dismissed about 47 judges and prosecutors, while 70 cases are pending. Only 2 judges have been fired because the Public Commissioner withdrew from the appeal. The Independent Qualification Commission has so far confirmed 101 magistrates, including 44 judges, 48 prosecutors and 9 legal assistants. Dismissed by the KPC by 2020 are 90 magistrates, of whom 56 are judges, 32 prosecutors. 5 members were dismissed from the Constitutional Court, 3 resigned and 1 member was confirmed in office. 7 members have been dismissed from the Supreme Court, 2 have been confirmed and 8 have resigned.

Almost in every dismissal decision, the lack of justification of wealth constitutes one of the fundamental motivations of the decision. In truth, they are made thorough checks that will concern not only the magistrates but also their rela- 
tives. For example, access to banks and financial institutions is envisaged; credit card checks, hotels, holidays, airport operators. Furthermore, it is possible to request information from other countries on data and financial movements, etc. (Baze, 2019). From these data it emerges that of all the subjects up to now subject to Vetting 60\% (adding even those discharged) remained outside the system. The reform has great expectations both from Albanian citizens and from the international community that has invested heavily in it.

The members of the Independent Qualification Commission, who process vetting cases in first instance, have almost reached their 100th decision in less than a year from the first vetting hearing. At the same time, the foundations for the new institutions that will guarantee the independent self-governing of the judiciary have been laid and the two new High Judicial and High Prosecutorial Councils have just held their respective constitutive sessions. These achievements follow months of hard work and challenges, some of which seemed difficult to overcome at some point (EWB, 2019).

The European Commission was encouraged to learn from the EU and US delegates for the vetting process, who are closely overseeing this process as part of the International Monitoring Operation, that vetting investigations are conducted thoroughly and professionally (Delegation of the European Union to Albania, 2016). While most appeals are still pending, one can see that this process is already yielding results. This enormous operation, and the high number of dismissals, led to the postponement of the formation of new judicial institutions and impacted the functioning of judicial institutions. But as problematic as they are, the temporary restrictions in the functioning of the justice system, which even resulted in the loss of quorum at the Constitutional Court, are unavoidable to build a judiciary that Albanian citizens can trust to honour the rule of law above everything else. With the creation of the new Justice Appointment Council, along with the new separated High Prosecutorial Council and High Judicial Council, a call goes to all the newly appointed members to live up to their duty at best, which is to ensure that the judiciary can function independently, free from any undue influence or pressure from politics or from any other external force. It is also very important that all the authorities responsible to appoint members at the Constitutional Court will exercise their duties in a timely and professional manner.

The most recent developments show that the reform is delivering, and that Albania is on a good path towards the establishment of a justice system free of incompetence, bias and corruption. The past year has seen the initiation of a process that will take time, and the vetting itself is only a small part of the judiciary reform and overall transformation Albania will continue to go towards in the future for the consolidation of the rule of law. This is what citizens of Albania deserve and want, and therefore the EU will continue accompanying the institutions of Albania in this historical endeavor. The vetting process is projected to last 9 years, i.e. until 2024. 


\section{EU Contribution to Albania's Reform of Justice}

The justice reform is one of the fields in which, the EU has been giving most support to Albania. It was a reform mainly financed by the EU EURALIUS (Agricultural and Agrifood Cooperative) mission, with the assistance also of the OPDAT (Department of Justice) USA and the c.d. Venice Commission, which depends on the EU and whose task is to monitor constitutional reforms in Eastern European countries (European Commission, n/a, b). The process is evaluated positively so far. According to The Hague, regarding the reform of justice, Albania has made important progress towards the implementation of a comprehensive justice reform package (Center for International Legal Cooperation, 2018). The progress consisted in increased professionalism, efficiency and independence of the judicial and prosecutorial systems, so far. The Hague stated that Albania's justice reform progress was of course not done alone, but was undertaken with the help of EU experts. In fact, the Netherlands holds a prominent position in international legal cooperation and distinguishes itself through international cooperation with a keen eye, and this is supported by the high ranking the Netherlands receives in various international rule of law related indexes, its internationally respected legal scholars and the many international legal institutions based in The Hague, the International City of Peace and Justice. In their word, they also stated that the results of these efforts have been recognized by both European Union institutions and EU Member States and many international actors also. What was interesting in their report was the fact that the Albanian "model" is currently perceived as a good-practice template for the implementation of justice reforms across the Western Balkans and EU neighborhood countries. Albania has moved even beyond reforms undertaken by some EU member states with its up and running reform programme. "The Albanian reforms are by no means cosmetic and can be considered a courageous effort, unique in its field" stated Robert Bosch, former head of the OSCE mission in Albania and moderator of the CILC roundtable (Center for International Legal Cooperation, 2018).

The EU contribution to Albania's reform of justice has been technical, financial, etc. In this context, EU and Albania signed the financing agreement for the Instrument for Pre-Accession Assistance (IPA-IPA II since 2015). In June 2014, the EU granted Albania candidate status in recognition of reforms that had been initiated. In view of the accession, the EU is calling for a reform of the judiciary, among others, which the IRZ has contributed to considerably as part of the EURALIUS IV project since the autumn of 2014 (IRZ, 2019). Financial assistance under IPA II (European Commission, n/a, a), the funding allocation for the 2014-2020 period is $€ 649.4$ million. IPA II contribution to judicial reform is linked to decision-making processes follow performance monitoring based on the quality of statistical data collected and analyzed in accordance with EUROSTAT standards, as well as functioning enough capacity to manage the EU membership process, including policy development, and the preparation and implemen- 
tation of appropriate legislation. And finally, strengthen the role of civil society in democratic processes and increase the independence of civil society from foreign donor funds. Previous IPA Assistance (European Commission, 2014) focused on key institutional reforms and capacity building of various judicial actors, mainly through assistance to modernize the justice system. In this regard, various donors are offering support in the area of justice and fundamental rights, such as Sweden, Italy, the Netherlands, and the United States and the United Nations.

The objective of future IPA III assistance is to strengthen democratic institutions, support the public administration reform process and improve public service delivery for the preparation and implementation of national legislation in accordance with European standards and best practices. Another objective is to improve economic governance and support for the implementation of a comprehensive public financial management reform. Support for civil society aims at further deepening of democratic culture in the country through the creation of an appropriate environment and capacity building of various actors.

Expected results to be achieved with EU assistance and their contribution to judicial reform is to strengthen democratic institutions in accordance with the legal framework and guarantee for consensus building to support EU reforms. To fully define the civil service and organizing public administration, coordination, and functioning, including the competencies and responsibilities of local government to increase capacity in providing services to citizens and businesses; functioning of a depoliticized and merit-based civil service with integrity systems and ethical standards. Also, improving the legal predictability and enforcement of laws and court decisions in the interests of businesses and citizens and functioning of tax and customs administrations in accordance with EU rules to guarantee an efficient system in the fight against corruption.

\section{The Current Progress of Albania into Adapting the Juridical Reform}

The implementation of the juridical reforms is still an ongoing process, strongly encouraged and supported by the EU. Along with the progress measured from the European Commission progress report and based on the recommendation of EU which emphasised the importance for Albania to continue on pursuing a sector approach to the justice reform under the cross-cutting strategy for 2017-2020 and ensure adequate governance, monitoring and reporting instruments through well-developed indicators coupled with adequate financial support for its implementation (European Commission, 2018). Albania has established a national strategy to measure the progress done by each institution. The progress is measured through 8 main objectives and sub-activities related to each of this objectives. Regarding Albania's progress report and monitoring Cross-Cutting Justice Strategy Action Plan 2017-2020 (Ministry of Justice, 2018), the status of the sub-activities provided for in the Action Plan of the Cross-Sectorial Strategy of 
Justice, results that for 2017 there have been realized 59 of them, 35 are still under implementation and 107 unfinished sub-activities (out of which 65 sub-activities are under the area of responsibility of the new justice system institutions, which in 2017 were not yet established). In 2018, out of 201 sub-activities provided for in the Strategy Action Plan, 73 of them have been implemented, 25 are still in the process of implementation and 103 unfinished sub-activities (out of which 65 sub-activities are in the field of the responsibility of the new justice system institutions). Percentage to total progress in implementing the Action Plan for 2017 is at $29 \%$ for the under-implemented activities, $18 \%$ under-activities underway and 53\% unfinished sub-activities. Percentage of the total progress of implementation of the Action Plan for 2018 is 36\% for the sub-activities that have been implemented, $13 \%$ for sub-activities in process, $51 \%$ for the sub-activities to be implemented in followed by responsible institutions. As above, it turns out that for the year 2018, 14 sub-activities were carried out more than 2017, while sub-activities in the process were reduced by 10 compared to the previous year. The number of unrealized sub-activities is 4 less than 2017 (Ministry of Justice, 2018: p. 28).

According to European Commission on the other hand, the Albanian juridical system has some level of preparation based on the implementation of the justice reform, which has resulted in good progress overall (European Commission, 2019). An important step in strengthening the independence and accountability of the judiciary has been the establishment of new institutions, such as the High Judicial Council, the High Prosecutorial Council and the Justice Appointment Council (European Commission, 2019). European Commission also highlighted that the vetting process has advanced steadily, producing tangible results. This is based on the reports of the International Monitoring Operation, under the aegis of the European Commission. International Monitoring Operation has continued to evaluate the concrete and credible results of the process, which have substantially strengthened the sector (European Commission, 2019). Thus, the judiciary system has been more independent, impartial, professional and accountable.

According to the EU Commission Progress Report, the country has some level of preparation in the fight against organized crime. An important element to consider here is the intensified cooperation with international police, especially of EU Member States. However, efforts need to continue regarding money laundering and confiscating assets of crime (European Commission, 2019).

In the latest European Commission Staff Working Document regarding the implementation of the EU-related reforms, (European Commission, 2020) the Republic of Albania has progressed toward:

- Advancing of the vetting process.

Vetting institutions, such as the Independent Qualification Commission, the Public Commissioners and the Appeal Chamber are working successfully under the oversight of the International Monitoring Operation and with the United 
States of America. As a result, $60 \%$ of the vetted magistrates were either dismissed or they reigned (European Commission, 2020). A redistribution plan is being implemented to fill the gaps in courts and prosecution offices.

- Finalizing the establishment of the independent juridical structures based on the constitutional reform.

High Judicial Council, High Prosecutorial Council, Justice Appointment Council, High Justice Inspector have been operating effectively (European Commission, 2020). Judges of the High Court are selected by the High Juridical Council by promoting magistrate candidates within the court system.

- Finalizing the establishment of the Special Anti-Corruption and Organized Crime Structure (SPAK) and National Bureau of Investigation (NBI) and Court. The Special Prosecution Office within SPAK is functional. Also, two EU experts are appointed to the NBI.

- Strengthening the track record of proactive investigations, prosecutions and final convictions in the fight against corruption, including at high level.

- The Anti-Corruption Task Force and the Anti-corruption directorate in the Ministry of Justice have been established. Also, the vetting process has shown concrete results in the fight against corruption, including Constitutional Court and High Court level.

- Strengthening the track record of proactive investigations, prosecutions and final convictions in the fight against organized crime.

Albanian Police in collaboration with EU Member States and Europol have been successful in arresting members of organized criminal groups.

The abovementioned conditions were met, so the EU Commission decided to open the accession negotiation with Albania in 2019. Also, another important decision of the European Council on to open membership negotiations with the Republic of Albania followed on 26.03.2020. This is a great responsibility for the Albanian government in terms of timely and proper fulfillment of all requirements, in accordance with the expectations of the EU membership process.

\section{Conclusion}

All the reforms in Albania, as well as the cross-cutting strategies, specifically aimed to strengthen the integrity of the public administration; stability of the public administration and support the independence and/or functional autonomy of key institutions. Also the reform is aiming to strengthen and promote trust in interinstitutional cooperation; also increasing the accountability of public officials, while performing their duties. The reform aims to make a greater and relevant involvement of the civil society, private sector and academia in drafting, implementing and monitoring legal initiatives, strategies and programs against corruption and fundamental rights (Muçollari \& Muharremaj, 2018). The seven (7) pillars of justice reform in Albania include: the justice system under the Constitution and the Constitutional Court; juridical power; criminal justice; legal education; legal services and free professions; measures in the fight 
against corruption; funding and infrastructure support of the system.

The first step of the juridical reform in Albania included the constitutional amendments of 21 July 2016, where out of 26 articles of the Albanian Constitution pertaining to the justice system, the Reform amended 21 of them, and at least 23 new points are added (Constitution of the Republic of Albania, Article $125,126,127,128,131,147 / a)$. Furthermore, the three institutions set out in the Constitution were merged and the creation of at least 12 new institutions was envisaged, such as a new special prosecution office against corruption and organized crime, a new specialized court against corruption, reorganized judicial and prosecutorial councils, National Bureau of Investigation, judicial appointments councils and a new office of the High Inspector of Justice. Some important laws resulted as part of the constitutional amendments are: Law No. 98/20169, which regulates the organization and functioning of the court system, Law No. 99/2016, which defines the rules of organization and functioning of the Constitutional Court and Law No. 115/201610 which defines rules for the organization and functioning of the High Judicial Council.

The second step was the adoption of the constitutional amendments followed by the adoption of the package of Organic Laws, which highlights the law on the temporary re-evaluation of judges and prosecutors of the Republic of Albania, called also "the vetting process". Its aim is to evaluate the integrity of public officials in fulfilling their duties. Part of the process is the collection of evidence of judges and prosecutors. The evidence will be evaluated in three main parts: the patrimonial evaluation (using the lawfully origin, figure control (personal and family) and finally the professional assessment skills. Until now, this process has resulted to $60 \%$ dismissal or resignations of vetted magistrates. However, this process must work with a faster pace and better quality in the formatting of institutions.

Throughout the process of EU integration, European Union has continually encouraged and supported Albania to start and intensify efforts to implement the reforms. The justice reform is one of the fields, in which most support has been given to Albania by the EU. The EU contribution to Albania's reform of justice has been technical, financial, etc. IPA I (2007-2013) Assistance (European Commission, 2014) focused on key institutional reforms and capacity building of various judicial actors, mainly through assistance to modernize the justice system. Moreover, IPA II (2014-2020) contribution to judicial reform is linked to decision-making processes follow performance monitoring based on the quality of statistical data collected and analyzed in accordance with EUROSTAT standards, as well as functioning enough capacity to manage the EU membership process, including policy development, and the preparation and implementation of appropriate legislation. And finally, strengthen the role of civil society in democratic processes and increase the independence of civil society from foreign donor funds.

The objective of future IPA III assistance is to strengthen democratic institu- 
tions, support the public administration reform process and improve public service delivery for the preparation and implementation of national legislation in accordance with European standards and best practices. Another objective is to improve economic governance and support for the implementation of a comprehensive public financial management reform. Support for civil society aims at further deepening of democratic culture in the country through the creation of an appropriate environment and capacity building of various actors.

Being determined to accelerate the process of EU membership with EU support in conducting reforms, the Albanian juridical system has some level of preparation based on the implementation of the justice reform. It has advanced the vetting process, has finalized the establishment of the independent juridical structures based on the constitutional reform; has established the Special Anti-Corruption and Organized Crime Structure (SPAK) and National Bureau of Investigation (NBI) and Court; has strengthened the track record of proactive investigations, prosecutions and final convictions in the fight against corruption, including at high level and the organized crime. As a result, European Commission opened the accession negotiations with Albania in 25 March 2020. This is not only a great opportunity but also a responsibility for the Albanian government in terms of timely and proper fulfillment of all requirements, in accordance with the expectations of the EU membership process. The juridical process implementation must be fair, objective and at a much better pace, eliminating some procrastination issues that may create misperceptions about the process. Also, the new institutions created in the framework of the justice system which must prove responsibility, proactive role and much better transparency in their decision-making.

Even though Albania is a country which has suffered a 30 year transition after the fall of the regime communism, it gives a message that even for countries which have a solid democracy always there is room for changes especially on reducing costs, be more productive and transparent and therefore be more effective for the citizens and to be for the citizens.

\section{Conflicts of Interest}

The author declares no conflicts of interest regarding the publication of this paper.

\section{References}

Baze, M. (2019). Justice Reform Is to Blame. http://www.gazetatema.net/2019/02/10/reforma-ne-drejtesi-e-ka-fajin

Bogdani, M. (2017). Fighting Corruption and Organized Crime in Albania through SPAK Authorities-Novelties on Constitutional and Legal Approach in Reflection of Best International Standards and Practices, Tirana.

Center for International Legal Cooperation (2018). The Hague/Albania Justice Reform "of Historic and Unprecedented Magnitude".

https://www.cilc.nl/the-hague-albania-justice-reform-of-historic-and-unprecedentedmagnitude 
Constitution of the Republic of Albania, Article 125, 126, 127, 128, 131, 147/a. https://www.venice.coe.int/webforms/documents/default.aspx?pdffile=CDL-REF(2016) $\underline{064-\mathrm{e}}$

Council of Europe (2016a). Albania Amicus Curiae Brief for the Constitutional Court on the Law on the Transitional Re-Evaluation of Judges and Prosecutors (The Vetting Law), Adopted by the Venice Commission.

http://www.venice.coe.int/webforms/documents/default.aspx?pdffile=CDL-AD(2016)0 $\underline{36-\mathrm{e}}$

Council of Europe (2016b). Albania Constitution, Article 125, 126, 127, 128, 131, 147/a. https://www.venice.coe.int/webforms/documents/default.aspx?pdffile=CDL-REF(2016) $\underline{064-\mathrm{e}}$

Delegation of the European Union to Albania (2016). Time for Change in the Albanian Judiciary: Looking Back at a Year of Vetting Process.

https://eeas.europa.eu/delegations/albania/56091/time-change-albanian-judiciary-looki ng-back-year-vetting-process_en

European Commission (2014). Instrument for Pre-Accession Assistance (IPA II). https://punetejashtme.gov.al/wp-content/uploads/2018/10/dokumenti-strategjik-komb tar-2014-2020_alb-1.pdf

European Commission (2016). Commission Staff Working Document, Albania 2016 Report. http://dap.gov.al/publikime/dokumenta-strategjik/63-progres-raportet

European Commission (2018). Commission Staff Working Document, Albania 2018 Report (pp. 16-17).

https://ec.europa.eu/neighbourhood-enlargement/sites/near/files/20180417-albania-rep ort.pdf

European Commission (2019). Commission Staff Working Document, Albania 2019 Report. http://dap.gov.al/publikime/dokumenta-strategjik/63-progres-raportet

European Commission (2020). Commission Staff Working Document, Update on the Republic of Albania.

https://ec.europa.eu/neighbourhood-enlargement/sites/near/files/update-on-the-republ ic-of-albania.pdf

European Commission (n/a, a). Albania-Financial Assistance under IPA II. https://ec.europa.eu/neighbourhood-enlargement/instruments/funding-by-country/alb ania_en

European Commission (n/a, b). Consolidation of the Justice System in Albania. https://ec.europa.eu/budget/euprojects/consolidation-justice-system-albania_en

European Union (2017). Justice Reform Collection of Laws, Publication of the School of Magistrate and Euralius, Tirana.

https://www.euralius.eu/index.php/en/library/albanian-legislation/send/103-justice-ref orm-collection-of-laws/216-justice-reform-collection-of-laws-en

EWB (2019). Albania on Good Path towards Establishment of Independent Judicial System.

https://europeanwesternbalkans.com/2019/01/05/albania-good-path-towards-establish ment-independent-judicial-system

Exit News (2020). 3 Years since the Establishment of KPC and KPA-Balance Sheet So Far. https://exit.al/3-vite-nga-krijimi-i-kpk-dhe-kpa-bilanci-i-vetingut-deri-tani

Fortuzi, A. (2019). Budget 2020/Justice Reform in focus, ALL 371 Million for SPAK. https://ata.gov.al/2019/11/20/buxheti-2020-reforma-ne-drejtesi-ne-fokus-371-milione-1 eke-per-spak

IBNA (2020). Albania: Justice Reform Must Continue with More Determination, Says 
Calavera.

https://balkaneu.com/albania-justice-reform-must-continue-with-more-determination -says-calavera

IRZ (2019). Albania: Consolidation of the Justice System in Albania (EURALIUS V). https://www.irz.de/index.php/en/projects/232-projekte-archiv/624-albania-consolidati on-of-the-justice-system-in-albania-euralius-iv

Law 95/2016 "On the Organization and Functioning of Institutions for Combating Corruption and Organized Crime", Called as Law on SPAK, Art. 43/7.

https://euralius.eu/index.php/en/library/albanian-legislation/category/360-laws

Law No. 115/2016 "On the Governance Bodies of the Justice System”. https://euralius.eu/index.php/en/library/albanian-legislation/category/360-laws

Law No. 84/2016 "On the Provisional Reassessment of Judges and Prosecutors in the Republic of Albania”.

https://euralius.eu/index.php/en/library/albanian-legislation/category/360-laws

Law No. 98/2016 "On the Organization of Judicial Power in the Republic of Albania”. https://euralius.eu/index.php/en/library/albanian-legislation/category/360-laws

Lexferanda (n/a). Vetting.

Likmeta, B. (2019). Albania's Kafkaesque Justice Reform Is Undermining Public Trust. https://balkaninsight.com/2019/03/07/albanias-kafkaesque-justice-reform-is-undermin ing-public-trust/?nocache $=1$

Marini, M. (2018). The 2019 Budget Supports Justice Reform.

Merruko, R. (2017). Albania: Role of International Actors in the "Vetting" Process. http://www.mondaq.com/x/550690/Constitutional+Administrative+Law/Role+Of+Int ernational+Actors+In+The+Vetting+Process

Ministry of Justice (2018). Monitoring Report January-December 2018, Cross-Cutting Justice Strategy 2017-2020.

https://drejtesia.gov.al/wp-content/uploads/2019/03/Raporti-i-Monitorimit-Vjetor-201 8-t\%C3\%AB-Strategjis\%C3\%AB-Nd\%C3\%ABrsektoriale-t\%C3\%AB-Drejt\%C3\%ABsis \%C3\%AB.pdf

Ministry of Justice (2020a). Speech of Minister Gjonaj in the Assembly Dated 18.06.2020. https://drejtesia.gov.al/newsroom/fjalime/fjala-e-ministres-gjonaj-ne-kuvend-date-1806-2020

Ministry of Justice (2020b). Reform, Gjonaj Brings Together the Diplomatic Corps and the New Judiciary: Our Responsibility to Restore the Hope of the Citizens in Trust, to Despise the Attack and the Mud.

https://drejtesia.gov.al/newsroom/njoftime/reforma-gjonaj-ben-bashke-trupin-diplom atik-dhe-organet-e-reja-te-drejtesise-pergjegjesia-jone-ta-kthejme-shpresen-e-qytetare ve-ne-besim-te-perbuzim-sulmin-dhe-balten

Muçollari, O., \& Muharremaj, E. (2018). The Judicial Reform, the Effect of Decentralization of Public Services and Good Governance on Combating Corruption. Tirana.

Murati, E. (2019). The European and American Attempt to Reform the Albanian Justice System: Where Are We at? https://www.albanianews.it/notizie/opinioni/vetting-albania

Shteti Web (2016). Who Performs the Vetting? http://shtetiweb.org/2016/10/12/kush-e-kryen-vetingun

Skëndaj, E., Caka, F., \& Bogdani, M. (2018). Study Report, Monitoring the Vetting Process of Judges and Prosecutors in the Period January 2017-June 2018, Albanian Helsinki Committee (p. 9).

http://www.osfa.al/sites/default/files/raport-studimor-monitorimi-i-procesit-te-vetting ut-te-gjyqtareve-dhe-prokuroreve_jan17-qer18.pdf 